\title{
SELF-INFLICTED PENETRATING CARDIAC INJURY: TWO DIFFERENT SURGICAL APPROACHES
}

\author{
Vladimir Stojiljković ${ }^{1}$, Saša Živić1 ${ }^{\text {, Dejan Perić }}{ }^{1}$, Aleksandar Kamenov ${ }^{1}$, \\ Nenad Paunović ${ }^{1}$, Marko Gmijović ${ }^{3}$, Dragan Milić1,2
}

\begin{abstract}
Penetrating cardiac injuries represent a great challenge for the surgeon because of their lethality. It is estimated that more than $90 \%$ of mortality happens before the patient reaches the hospital and survival after stab wounds to the heart is about $50 \%$ as opposed to $11 \%$ after gunshot wounds.

A 58-year-old hemodynamically unstable male was brought to the ED with two stab wounds to the left chest. Two surgical approaches were applied to treat the injury. First, urgent left antero-lateral thoracotomy with left ventricle suture repair was performed. Few hours later, due to massive bleeding and hemodynamic instability, left ventricle repair through a median sternotomy with extracorporeal circulation and cardiac arrest was performed.

Heart injuries can be treated with two surgical approaches. Left thoracotomy can be feasibly applied in emergency department but median sternotomy provides better access to the heart and all important cardiovascular structures.

Prompt and early diagnosis associated with a well-trained surgical team can be crucial in the management of life-threatening cardiac injuries.
\end{abstract}

Acta Medica Medianae 2020;59(2):88-92.

Key words: penetrating, heart, injury

\footnotetext{
${ }^{1}$ Department of Cardiac surgey, Clinical Center of Niš, Niš, Serbia

${ }^{2}$ University of Niš, Faculty of Medicine, Niš, Serbia

${ }^{3}$ Digestive Surgery Clinic, Clinical Center of Niš, Serbia
}

Contact: Vladimir Stojiljković

Cvijićeva 9/18, 18000 Niš, Serbia

E-mail: serbvlada@yahoo.com injuries. The left atrium is the least likely injured because of its small size and well-protected posterior location $(4,5)$.

Historically, on July 10,1893, Dr. Daniel Hale Williams, a surgeon from Chicago, successfully operated on a 24-year-old man who had been stabbed in the heart during a fight. The wound in the right ventricle was not bleeding, so Williams did not place a stitch through the heart wound. He did, however, stitch close the hole in the pericardium. This operation is probably the first successful surgery involving a documented stab wound to the heart. Dr. Ludwig Rehn, a surgeon in Frankfurt, Germany, performed what many consider the first successful heart operation. On September 7, 1896, he operated a 22-year-old man who was stabbed in the heart. In Serbia (Valjevo), Dr. Jovan Mijušković performed first successful open-heart surgery.

On April 7, 1928 he operated on fifteen-yearold Dragomir Mitrović, inadvertently wounded in a small-caliber handgun.

\section{Case report}

A 58-year-old male was referred to our hospital Emergency Department at 07.00 AM for self-inflicted, two stab wounds of the left chest. At his arrival, patient was hemodynamically unstable with immeasurable blood pressure, heart rate of 120 and respiratory frequency of 30 . During physical heart and thus is the most vulnerable to penetrating 
examination, the presence of two stab wounds in the $4^{\text {th }}$ intercostal space over the midclavicular line, on the left hemithorax, were noticed. A thoracic Xray showed the presence of a left hydropneumothorax. The patient was brought to the operating room and the chest tube was inserted at posterior axillary line in the 5th intercostal space. In a few seconds about $2000 \mathrm{ml}$ of blood drained. An urgent left antero-lateral thoracotomy was performed. After opening the pericardium, penetrating injury of the left ventricle lateral wall was observed. Hemostasis was achieved by placement of two " $U$ " sutures (Prolene 3-0). The patient was transferred to the Intensive Care Unit.
Because of massive bleeding and hemodynamic instability, the patient was brought to the operating room again at $11.00 \mathrm{AM}$. This time, median sternotomy was performed. Two bleeding sites were noticed: one on the left ventricle lateral wall, which was treated during the first operation, and the other one on the left ventricle anterior wall (Figure 1). Both lesions were treated with pledget enforced, "U" sutures (Prolene 3-0), on a beating heart and subsequent fibrin sealant application (Beriplast ${ }^{\circledR} \mathrm{P}$ Combi Set, CSL Behring). Hemostasis was achieved, two chest tubes were inserted and the patient was transferred to the Intensive Care Unit.

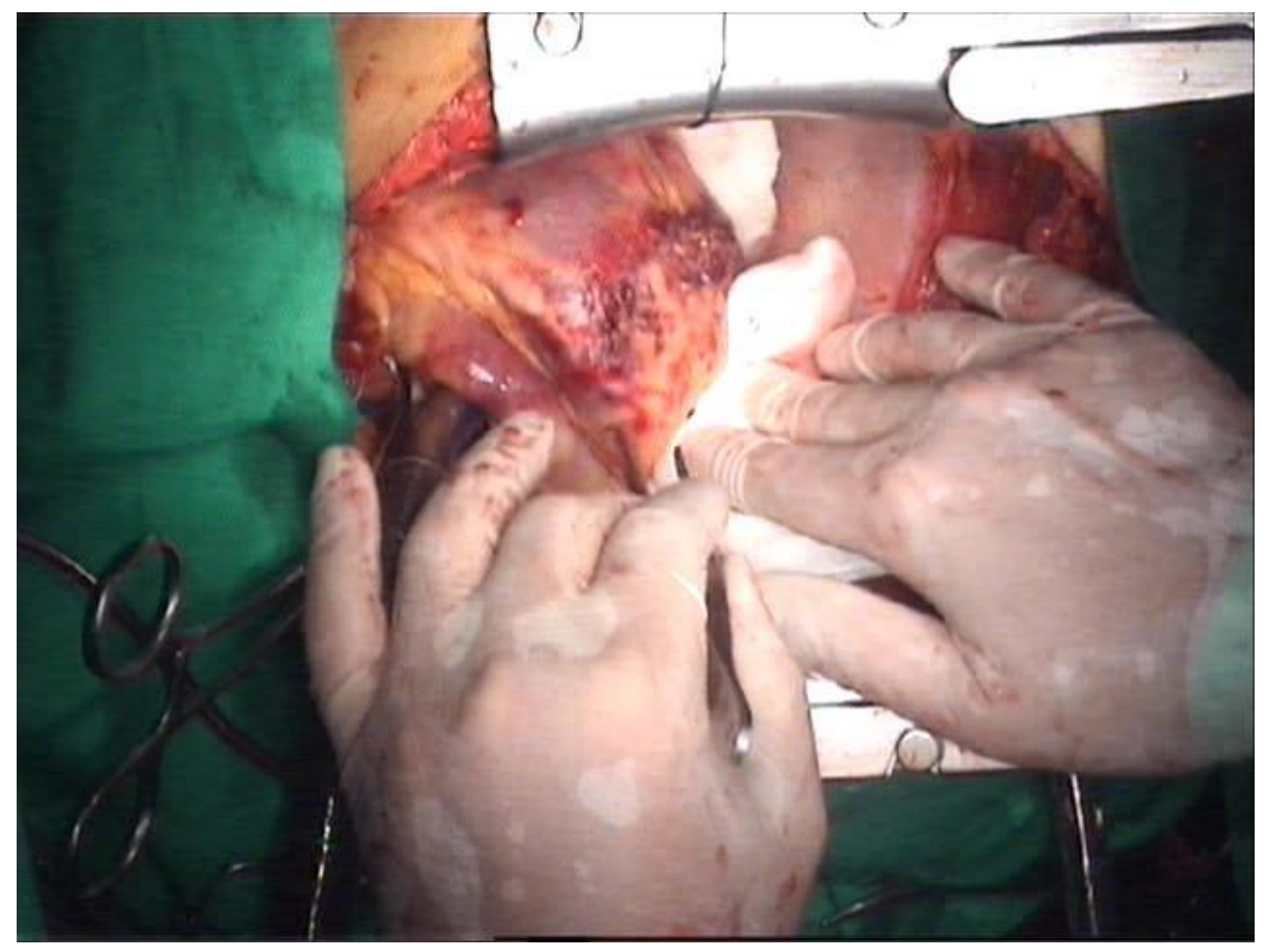

Figure 1. Two penetrating injuries on anterolateral wall of the left ventricle

Around 03.00 PM, suddenly, massive bleeding of about $700 \mathrm{ml}$ of blood occurred again. The patient was immediately transferred to the operating room. After resternotomy, massive bleeding from previously treated lesions was noticed. This time, it was decided to repair left ventricle penetrating injuries using extracorporeal circulation and cardioplegic arrest. After heparin administration, arterial and venous cannulation was performed, aorta was clamped and $1150 \mathrm{ml}$ of cold crystalloid cardioplegia solution was administered. After the heart stopped, all previously posted sutures were removed. Both lesions were treated with the same approach. In the first layer, we used single "U" sutures (Prolene 3-0), enforced with $5 \mathrm{~cm}$ long teflon tapes on both sides of the lesions (Figure 2). In the second layer, teflon tapes were sutured with continuous over-over stitch (Prolene 3-0) (Figure 3). Hemostasis was achieved. The aortic cross clamp time was 34 minutes and extracorporeal circulation time was 79 minutes.

Postoperatively, the patient received 4 doses of resuspended red cells, 3 doses of fresh frozen plasma, 10 doses of cryoprecipitate and 20 doses of platelets. Postoperative care evolved without complications; the patient was discharged on the twelfth day. 


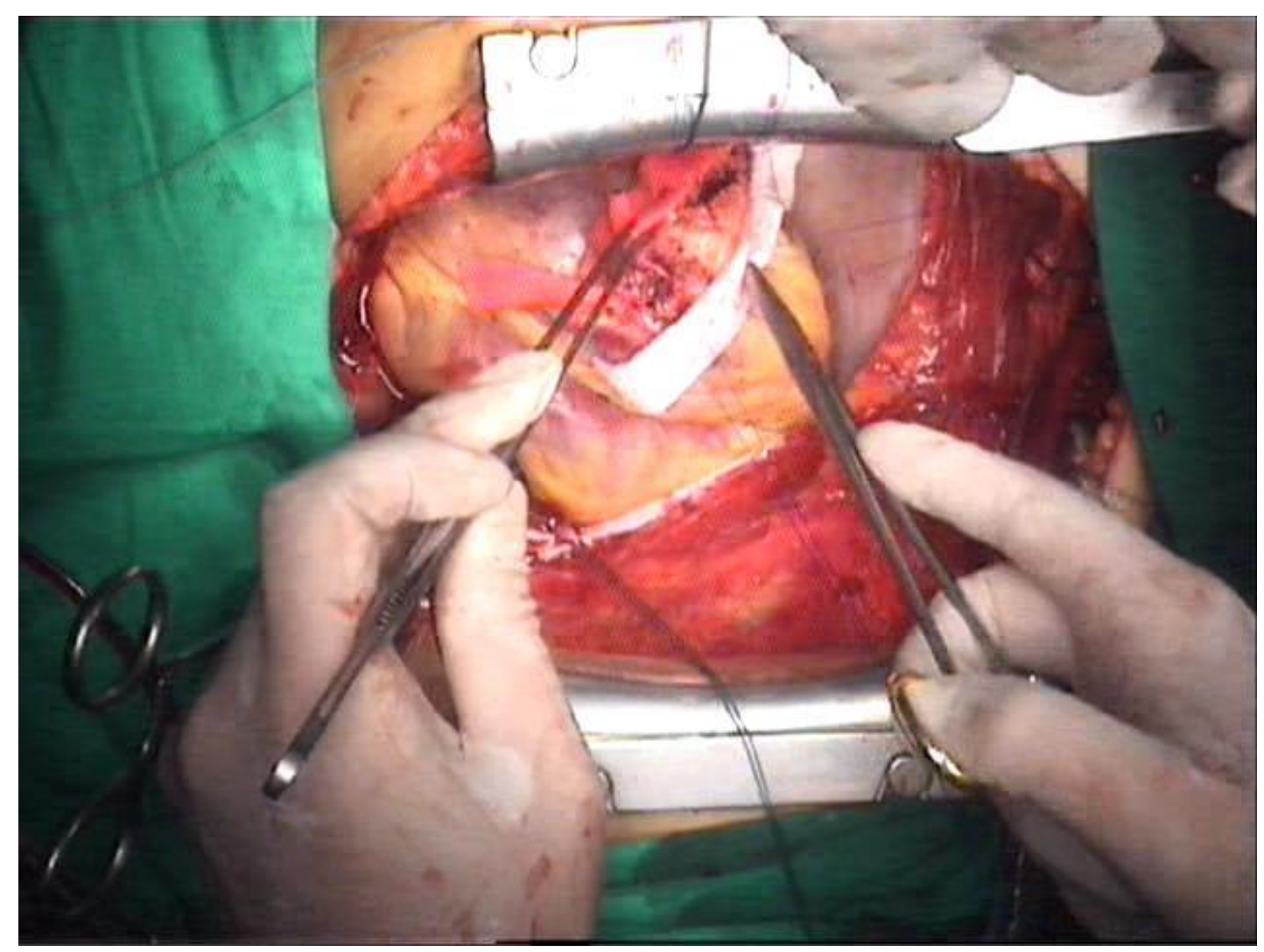

Figure 2. Left ventricle repair. First layer.

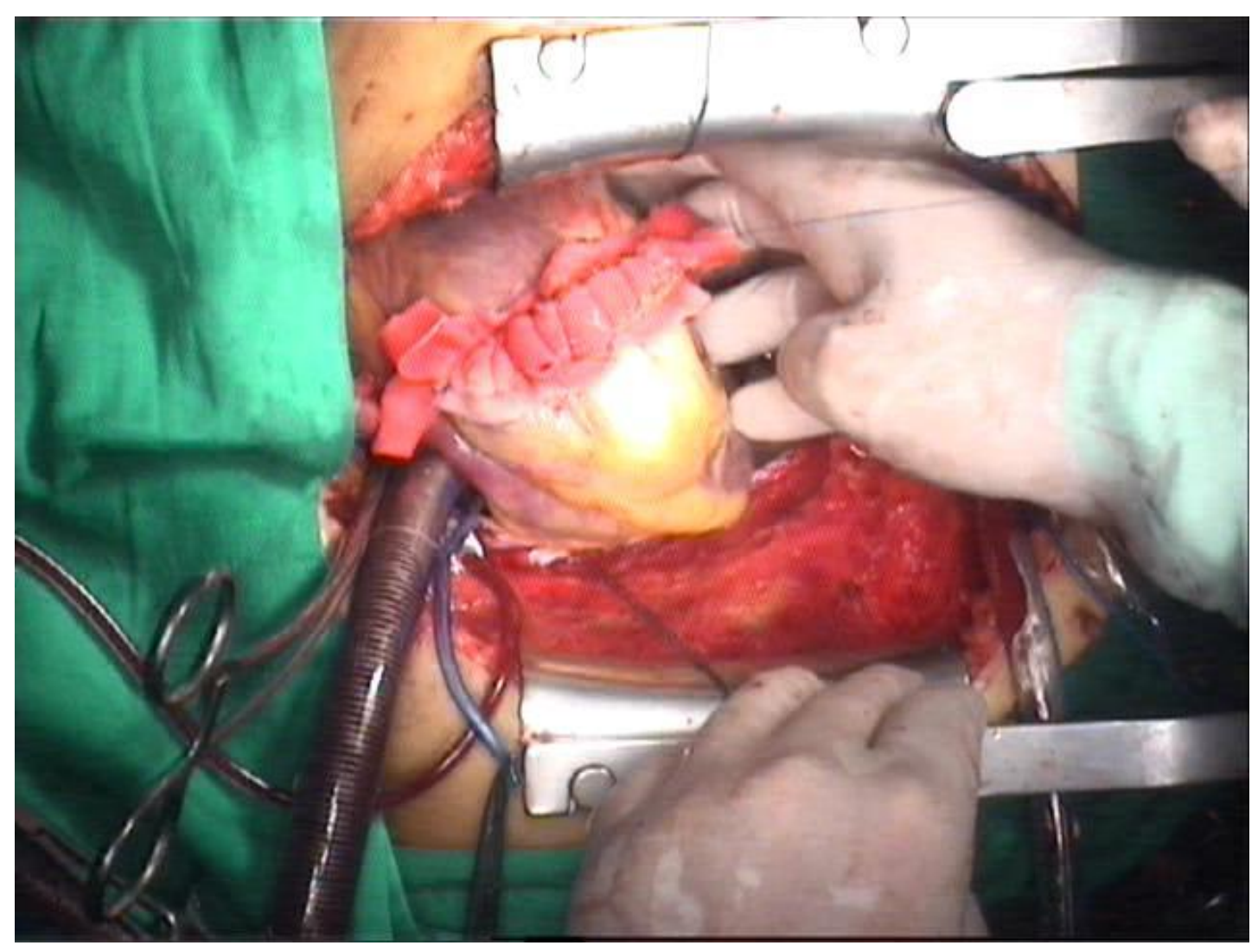

Figure 3. Left ventricle repair. Second layer. 


\section{Discussion}

There are two commonly involved mechanisms in PCI: gunshot wounds (GSW) or wounds with a sharp object (WSO), with a survival rate of GSW victims of $11 \%$ versus $50 \%$ for WSO victims. In our patient's case, his injury was self-inflicted using a nail (WSO). Early diagnosis can be crucial in the management of life-threatening cardiac injuries. Subxiphoid window and noninvasive studies, such as echocardiography, remain the gold standard for diagnosis. Echocardiography has become a standard in the care of stable patients, becoming the first option in the emergency room.

An unstable patient, with tamponade or hemodynamic instability, must be taken to the operating room to perform an emergency thoracotomy or a median sternotomy.

Surgical approach could be fundamental to control the bleeding. According to the available literature, the advantages of median sternotomy approach are effective and extensive vision of the heart, great vessels, other structures in the mediastinum and to both pleural cavities and also allowing cannulation for a cardiopulmonary bypass. On the other hand, left anterolateral thoracotomy provides rapid access to the right and left ventricles, facilitates access to posterior structures such as the esophagus, descending aorta, or left hilum and this is usual approach for emergency room thoracotomy. Nevertheless, the choice of surgical approach also depends on the surgeon's experience, the expected injuries according to the probable trajectory of the wounds, and the evidence of associated lesions (6, 7).

In our case, we were forced to apply both approaches to the same patient. The reason for this is the fact that the first surgery was performed by a team of thoracic surgeons and the other two operations by a team of cardiac surgeons. This confirms that the experience of the surgeon plays a very important role in the choice of surgical approach for PCI.

\section{Conclusion}

Prompt and early diagnosis associated with a well-trained surgical team can be crucial in the management of life-threatening cardiac injuries. The experience of the surgeon plays a very important role in the choice of surgical approach for PCI.

\section{References}

1. Campbell NC, Thomson SR, Muckart DJ, Meumann CM, Van Middelkoop I, Botha JB. Review of 1198 cases of penetrating cardiac trauma. Br J Surg 1997; 84:1737-40. [CrossRef] [PubMed]

2. Asensio JA, Berne JD, Demetriades D, Chan L, Murray J, Falabella $A$, et al. One hundred five penetrating cardiac injuries: a 2-year prospective evaluation. ] Trauma 1998;44:1073-82. [CrossRef] [PubMed]

3. Kang $N$, Hsee $L$, Rizoli $S$, Alison P. Penetrating cardiac injury: overcoming the limits set by Nature. Injury. 40 2009;40:919-27. [CrossRef] [PubMed]

4. Ezzine SB, Bouassida M, Benali M, Ghannouchi M, Chebbi $F$, Sassi $F$, et al. Management of penetrating cardiac injuries in the department of surgery,
Mohamed Thahar Maamouri Hospital, Tunisia: report of 19 cases. Pan Afr Med J 2012;11:54. [PubMed]

5. Clarke DL, Quazi MA, Reddy K, Thomson SR. Emergency operation for penetrating thoracic trauma in a metropolitan surgical service in South Africa. J Thorac Cardiovasc Surg. 2011;142:563-8. [CrossRef] [PubMed]

6. Degiannis E, Bowley DM, Westaby S. Penetrating cardiac injury. Ann R Coll Surg Engl. 2005;87(1):61-3. [CrossRef] [PubMed]

7. Embrey R. Cardiac trauma. Thorac Surg Clin. 2007; 17:87-93. [CrossRef] [PubMed] 


\title{
PENETRANTNA TRAUMA SRCA IZAZVANA SAMOPOVREĐIVANJEM - DVA RAZLIČITA HIRUŠKA PRISTUPA
}

\author{
Vladimir Stojiljković ${ }^{1}$, Saša Živić ${ }^{1}$, Dejan Perić ${ }^{1}$, Aleksandar Kamenov ${ }^{1}$, \\ Nenad Paunović ${ }^{1}$, Marko Gmijović ${ }^{3}$, Dragan Milić1,2
}

${ }^{1}$ Klinika za kardiohirurgiju, Klinički centar Niš, Niš, Srbija

2Univerzitet u Nišu, Medicinski fakultet, Niš, Srbija

${ }^{3}$ Klinika za digestivnu hirurgiju, Klinički centar Niš, Niš, Srbija

Kontakt: Vladimir Stojiljković

Cvijićeva 9/18, 18000 Niš, Srbija

E-mail: serbvlada@yahoo.com

Penetrantne povrede srca predstavljaju veliki izazov za hirurge, zbog visoke stope smrtnosti. Smatra se da preko $90 \%$ smrtnih ishoda nastupi pre dolaska bolesnika u bolnicu. Preživljavanje nakon ubodnih povreda srca je oko 50\%, dok je kod povreda izazvanih vatrenim oružijem oko $11 \%$.

U Urgentni centar primljen je pedesetosmogodišnji muškarac u hemodinamski nestabilnom stanju, sa dve ubodne rane u predelu leve strane grudnog koša. U cilju zbrinjavanja povreda, primenjena su dva hiruška pristupa. Prvo je urađena urgentna levostrana anterolateralna torakotomija sa suturom leve komore. Nekoliko časova kasnije, zbog obimnog krvarenja i hemodinamske nestabilnosti, urađena je rekonstrukcija leve komore, pristupom kroz medijalnu sternotomiju, uz pomoć vantelesnog krvotoka i na zaustavljenom srcu.

Postoje dva osnovna hiruška pristupa za zbrinjavanje penetrantnih povreda srca. Levostrana anterolateralna torakotomija omogućava brz pristup u jedinicama urgentnog zbrinjavanja, ali medijalna sternotomija obezbeđuje bolji pristup srcu i ostalim važnim kardiovaskulanim strukturama.

Brza i rana dijagnostika, udružena sa dobro obučenim hiruškim timom, od presudnog je značaja u zbrinjavanju smrtonosnih povreda srca.

Acta Medica Medianae 2020;59(2):88-92.

Ključne reči: penetrantna povreda, srce, povreda 